\title{
Effect of rumen-protected protein supplemented with three amino acids on milk yield, composition and fatty acid profile in dairy cows*
}

\author{
J. Třináctý1,3, L. Křížová1, S. Hadrová1, O. Hanušs ${ }^{1}$ B. Janštová 2 , \\ L. Vorlová ${ }^{2}$ and M. Dračková ${ }^{2}$ \\ ${ }^{1}$ Research Institute for Cattle Breeding, Ltd., Department Pohořelice \\ Vídeňska 699, Pohořelice 691 23, Czech Republic \\ ${ }^{2}$ Department of Milk Hygiene and Technology, Faculty of Veterinary Hygiene and Ecology, \\ University of Veterinary and Pharmaceutical Sciences \\ Brno, Czech Republic
}

(Received 24 June 2005; revised version 12 October 2005; accepted 6 January 2006)

\begin{abstract}
The objective of this study was to determine the influence of rumen-protected protein supplemented with the amino acids lysine (Lys), methionine (Met) and histidine (His) added either as a powder or in the form of rumen-protected tablets to the rumen of dairy cows on the yield, composition and technological suitability of milk. The experiment was carried out on three lactating Holstein cows with an average weight of $523 \mathrm{~kg}$ fitted with ruminal and duodenal cannulas. The experiment was divided into 4 periods of $14 \mathrm{~d}$ ( $10 \mathrm{~d}$ preliminary period and $4 \mathrm{~d}$ experimental period). In the first period one cow received the tablets $(\mathrm{T})$ and the other two received the non-tableted mixture $(\mathrm{C})$ with the same composition. In the subsequent period the design was opposite. Cows were fed a diet based on maize silage, lucerne hay and a supplemental mixture. Powder or tablets consisted of purified soya-protein HP 300, Lys, Met and His. Average milk yield in C cows was $16.73 \mathrm{~kg}$ and was significantly lower than in $\mathrm{T}$ cows $(17.8 \mathrm{~kg} ; \mathrm{P}<0.05)$. Protein, fat and lactose contents were unaffected by the treatment. Protein yield was lower $(529.5 \mathrm{~g} / \mathrm{d})$ in the $\mathrm{C}$ than in the $\mathrm{T}(569.3 \mathrm{~g} / \mathrm{d} ; \mathrm{P}<0.05)$ cows. The increase in milk protein yield in $\mathrm{T}$ cows was followed closely by progressive increases in casein content (2.46 vs 2.68\%). The content of short- and medium-chain fatty acids was higher and the proportion of C18:1, $\mathrm{C} 18: 2, \mathrm{C} 18: 3 \mathrm{n} 3$ and $\mathrm{C} 20: 1$ was lower in the $\mathrm{C}$ than in the $\mathrm{T}(\mathrm{P}<0.05)$ animals. The proportion of UFA (both MUFA and PUFA) was increased and that of SFA in milk $(\mathrm{P}<0.05)$ was decreased in the $\mathrm{T}$ animals. The total SFA:UFA ratio was higher in $\mathrm{C}$ compared with $\mathrm{T}$ cows $(1.89$ vs $1.52 ; \mathrm{P}<0.05)$.
\end{abstract}

KEY WORDS: amino acids, protein, rumen protection, dairy cow, lactation, milk, fatty acids

\footnotetext{
* Supported by the Grant Agency of the Czech Republic, Project No. 523/02/0164 and by the National Agency for Agriculture Research, Czech Republic, Project No. 1 B44037

${ }^{3}$ Corresponding author: e-mail: trinacty@vuvz.cz
} 


\section{INTRODUCTION}

The maximum production of animal protein (i.e. milk, meat etc.) is influenced by the amounts and percentages of individual digestible amino acids (AA) supplied in feed. To achieve and maintain high productivity it is necessary to meet postruminal digestible protein requirements. One of the most effective ways is to provide the deficient AA in a ruminally protected form.

Most studies (e.g., recently Rulquin and Delaby, 1997) agree that Lys and Met are the most critical amino acids for milk protein yield in dairy cows. Korhonen et al. (2000) mentioned His as the first limiting AA in diets based on grass silage and, according to Vanhatalo et al. (1999) His has been identified as a potentially limiting AA for milk production. Other authors mentioned as limiting the combinations of Met with Leu (Krober et al., 2001) and/or with His and Arg (Xu et al., 1998). The problem of limiting AA has been relatively well investigated in studies on the supply of Met and Lys but not enough data are available for other AA or their combinations.

Milk is considered to be an important part of human nutrition, however, it has a rather unfavourable fatty acid composition. From the viewpoint of human nutrition (i.e. with regard to the need to reduce plasma cholesterol) it is desirable to increase the content of $\mathrm{C} 18$ fatty acids (including stearic acid) and to decrease levels of myristic (C14:0) and palmitic (C16:0) acids. The results of experiments performed by Christensen et al. (1994) or Pisulewski et al. (1996) suggest that AA may have an impact on de novo synthesis of short- and medium-chain fatty acids in the mammary gland.

The objective of this study was to confirm the hypothesis that supplementing a rumen-protected mixture of soya protein and amino acids (Lys, Met and His) in the form of copolymer-coated tablets to the rumen of lactating dairy cows increases the milk protein content and yield in comparison with the non-protected powder form of the mixture.

\section{MATERIAL AND METHODS}

\section{Animals and procedures}

Three lactating Holstein cows (lactation 1-3) with similar milk production and mean liveweight $(523 \mathrm{~kg}$ ) were used in the experiment. The cows were fitted with duodenal and ruminal cannulas and were housed in individual tie stalls bedded with sawdust.

The experiment, starting on week 17-35 of lactation, was divided into 4 periods. Each period (14 d) consisted of a 10-day preliminary period and a 4-day experimental period. In the first period, one cow received the tablets $(\mathrm{T})$ and the 
other two received the non-tableted mixture (C) with the same composition. In the subsequent period, the design was opposite.

Cows were fed individually twice daily $(7.00$ and $16.35 \mathrm{~h})$ ad libitum with the diet based on maize silage, lucerne hay and a supplemental mixture (Table 1). The

Table 1. Composition of diet, in \% of DM

\begin{tabular}{lc}
\hline Component & $\%$ \\
\hline Maize silage & 54.7 \\
Lucerne hay & 15.0 \\
Supplemental mixture & 1 \\
\hline
\end{tabular}

${ }^{1}$ supplemental mixture contains, \%: barley 35.0 ; oat 30.0 ; wheat 10.0 ; sugar beet chippings 15.0 ; linseed 5.0; sodium chloride $(\mathrm{NaCl})$ 0.5; dicalcium phosphate (DCP) 1.5 ; limestone $\left(\mathrm{CaCO}_{3}\right)$ 1.5; sodium bicarbonate $\left(\mathrm{NaHCO}_{3}\right) 0.1$; monosodium phosphate (MSP) 0.2 ; magnesium phosphate (MgP) 0.2; trace elements and vitamin mixture 1.0

diets were formulated to meet energy and protein (Sommer et al., 1994) and amino acid (Rulquin et al., 2001) requirements. Refusals were registered every day. Rumen-protected tablets consisted of, \%: purified soya-protein HP 300, 93; Lys, 1.6; Met, 2.4 and His, 3.0. Daily intake of these ingredients were 306, 5.7, 8.8 and $10.6 \mathrm{~g}$, respectively. The tablets (diameter $6.5 \mathrm{~mm}$, lenticular in shape), produced by the authors according to Ardaillon et al. (1989), were coated by a copolymer according to patent No. US 4,877,621. The non-tableted mixture of soya-protein and three amino acids $(\mathrm{C})$ or tablets $(\mathrm{T})$ were applied during the whole period $(14 \mathrm{~d})$ twice a day just before feeding. The tablets or mixture were wrapped in filter paper and inserted into the bottom of the rumen via the ruminal cannula.

\section{Analytical procedures}

Proximal analyses of feeds and orts were carried out in each period according to AOAC (1984). Refusals were monitored daily, with an aliquot analysed.

Cows were milked twice daily at 7.15 and $17.15 \mathrm{~h}$. Milk samples were taken at each milking, conserved by 2-bromo-2-nitropropane-1.3-diol (Bronopol) and cooled to $6^{\circ} \mathrm{C}$. Milk composition was analysed by an infrared analyser (Bentley Instruments 2000, Bentley Instruments Inc., USA). The urea content was determined using an UREAKVANT apparatus.

Proportional samples (just cooled) were analysed for $\mathrm{pH}$, titratable acidity (Soxhlet-Henkel ${ }^{\circ} \mathrm{SH}$ ), milk conductivity (Milk Checker, Oriental Instruments Ltd., Japan), freezing point (Milk Cryoscope 4D2, Advanced Instruments, Inc., USA), free fatty acids, casein (precipitation with $10 \%$ acetic acid, measured on a Kjeltec auto, 1030). In addition, somatic cell count was measured on a Somacount 500 (Bentley Instruments Inc., USA). 
Extracted milk fat (50-60 mg) was dissolved in isooctane and homogenized by ultrasound. After the addition of sodium methanolate the mixture was heated under a reverse cooler. FA were released in the form of fatty acid methyl esters (FAMEs) which were separated using a HP 4890D gas chromatograph (HewlettPackard, USA) with an Omegawax TM250 capillary column $(30 \mathrm{~m} \times 0.25 \mathrm{~mm}$ i.d. $\times 0.25 \mu \mathrm{m}$ ). The temperature range was from 80 to $240^{\circ} \mathrm{C}$ with a temperature increase of $5^{\circ} \mathrm{C} / \mathrm{min}$. Injector and detector temperatures were 280 and $300^{\circ} \mathrm{C}$, respectively. Nitrogen was the carrier gas. FAMEs were detected with a flame ionization detector and identified according to retention times using Supelco 37 component FAME Mix (Supelco, USA) external fatty acid standards.

Statistical analysis

Data obtained in the experiment were analysed using the GLM procedure of the Statgraphics 7.0 package according to the following model:

$$
\mathrm{Y}_{\mathrm{ijk}}=\mu+\mathrm{T}_{\mathrm{i}}+\mathrm{C}_{\mathrm{j}}+\mathrm{T}_{\mathrm{i}} \mathrm{C}_{\mathrm{j}}+\mathrm{P}_{\mathrm{k}}+\varepsilon_{\mathrm{ijk}}
$$

where $\mu=$ general mean, $T_{i}=$ treatment effect $(i=2), C_{j}=$ cow effect $(j=3)$, $\mathrm{P}_{\mathrm{k}}=$ period effect $(\mathrm{k}=4)$ and $\varepsilon_{\mathrm{ijk}}=$ error term.

\section{RESULTS}

The intake of dry matter and other nutrients except fat and ADF was significantly lower $(\mathrm{P}<0.05)$ for cows receiving powder $(\mathrm{C})$ than for cows receiving tablets $(\mathrm{T})$, as presented in Table 2 .

Table 2. Nutrients intake

\begin{tabular}{|c|c|c|c|c|c|}
\hline \multirow{3}{*}{ Nutrient } & \multirow{3}{*}{ Unit } & \multicolumn{4}{|c|}{ Group } \\
\hline & & \multicolumn{2}{|c|}{$C^{1}(n=24)$} & \multicolumn{2}{|c|}{$\mathrm{T}^{2}(\mathrm{n}=24)$} \\
\hline & & mean & SEM & mean & SEM \\
\hline Dry matter & $\mathrm{kg}$ & $15.68^{\mathrm{b}}$ & 0.325 & $16.33^{\mathrm{a}}$ & 0.265 \\
\hline Organic matter & $\mathrm{kg}$ & $14.60^{\mathrm{b}}$ & 0.303 & $15.11^{\mathrm{a}}$ & 0.247 \\
\hline Crude protein & $\mathrm{kg}$ & $1.89^{\mathrm{b}}$ & 0.047 & $1.97^{\mathrm{a}}$ & 0.038 \\
\hline Fat & $\mathrm{kg}$ & 0.54 & 0.006 & 0.55 & 0.008 \\
\hline Crude fibre & $\mathrm{kg}$ & $2.29^{\mathrm{b}}$ & 0.057 & $2.37^{\mathrm{a}}$ & 0.049 \\
\hline $\mathrm{NDF}$ & $\mathrm{kg}$ & $5.23^{\mathrm{b}}$ & 0.124 & $5.43^{\mathrm{a}}$ & 0.102 \\
\hline $\mathrm{ADF}$ & $\mathrm{kg}$ & 3.14 & 0.068 & 3.20 & 0.060 \\
\hline Ash & $\mathrm{kg}$ & $1.09^{\mathrm{b}}$ & 0.022 & $1.22^{\mathrm{a}}$ & 0.018 \\
\hline $\mathrm{N}$-free extractives & $\mathrm{kg}$ & $9.59^{\mathrm{b}}$ & 0.211 & $9.88^{\mathrm{a}}$ & 0.168 \\
\hline PDIN & $\mathrm{kg}$ & $1.25^{\mathrm{b}}$ & 0.020 & $1.31^{\mathrm{a}}$ & 0.017 \\
\hline PDIE & $\mathrm{kg}$ & $1.31^{\mathrm{b}}$ & 0.024 & $1.43^{\mathrm{a}}$ & 0.020 \\
\hline NEL & MJ & $98.89^{\mathrm{b}}$ & 2.055 & $101.99^{\mathrm{a}}$ & 1.678 \\
\hline
\end{tabular}

a,b means in the same row with different superscripts differ significantly $(\mathrm{P}<0.05)$

${ }^{1}$ control group; ${ }^{2}$ experimental group 
Milk yield and composition are given in Table 3, daily yield of milk constituents is shown in Table 4. Milk yield and casein content recorded in $\mathrm{C}$ animals was significantly lower than in $\mathrm{T}$ cows $(\mathrm{P}<0.05)$. FCM in $4 \%$ yield did not differ significantly $(\mathrm{P}>0.05)$ between treatments. Although milk protein content did not show statistically significant variations $(\mathrm{P}>0.05)$ the milk protein yield from $\mathrm{C}$ cows was lower than from $\mathrm{T}(\mathrm{P}<0.05)$ animals. Furthermore, the increase in milk protein yield in $\mathrm{T}$ was followed closely by progressive increases in casein content and yield $(\mathrm{P}<0.05)$. Based on the data mentioned above, $\mathrm{C}$ milk had a lower proportion of casein proteins in total milk protein $(77.6 \%)$ than $\mathrm{T}$ milk $(83.5 \%)$.

Table 3. Milk yield and composition

\begin{tabular}{|c|c|c|c|c|c|}
\hline \multirow{3}{*}{ Component } & \multirow{3}{*}{ Unit } & \multicolumn{4}{|c|}{ Group } \\
\hline & & \multicolumn{2}{|c|}{$\mathrm{C}^{1}(\mathrm{n}=24)$} & \multicolumn{2}{|c|}{$\mathrm{T}^{2}(\mathrm{n}=24)$} \\
\hline & & mean & SEM & mean & SEM \\
\hline Milk yield & $\mathrm{kg} / \mathrm{d}$ & $16.73^{\mathrm{b}}$ & 0.383 & $17.80^{\mathrm{a}}$ & 0.281 \\
\hline $4 \% \mathrm{FCM}$ & $\mathrm{kg} / \mathrm{d}$ & 15.37 & 0.614 & 16.04 & 0.654 \\
\hline Dry matter & $\%$ & 11.94 & 0.183 & 12.02 & 0.154 \\
\hline Non-fat dry matter & $\%$ & $8.51^{\mathrm{b}}$ & 0.115 & $8.71^{\mathrm{a}}$ & 0.068 \\
\hline Protein & $\%$ & 3.17 & 0.088 & 3.21 & 0.062 \\
\hline Casein & $\%$ & $2.46^{\mathrm{b}}$ & 0.094 & $2.68^{\mathrm{a}}$ & 0.052 \\
\hline Fat & $\%$ & 3.43 & 0.156 & 3.31 & 0.191 \\
\hline Lactose & $\%$ & 4.75 & 0.035 & 4.81 & 0.032 \\
\hline Free fatty acids & $\mathrm{mmol} / \mathrm{kg}$ & 50.96 & 3.902 & 47.16 & 4.361 \\
\hline Urea & $\mathrm{mg} / 100 \mathrm{~mL}$ & $25.00^{\mathrm{b}}$ & 1.830 & $21.92^{\mathrm{a}}$ & 1.005 \\
\hline
\end{tabular}

${ }_{a, b}$ means in the same row with different superscripts differ significantly $(\mathrm{P}<0.05)$

${ }^{1,2}$ see Table 2

Table 4. Daily yield of milk components

\begin{tabular}{|c|c|c|c|c|c|}
\hline \multirow{3}{*}{ Component } & \multirow{3}{*}{ Unit } & \multicolumn{4}{|c|}{ Group } \\
\hline & & \multicolumn{2}{|c|}{$\mathrm{C}^{1}(\mathrm{n}=24)$} & \multicolumn{2}{|c|}{$\mathrm{T}^{2}(\mathrm{n}=24)$} \\
\hline & & mean & SEM & mean & SEM \\
\hline Dry matter & $\mathrm{kg} / \mathrm{d}$ & $2.00^{\mathrm{b}}$ & 0.059 & $2.14^{\mathrm{a}}$ & 0.049 \\
\hline Non-fat dry matter & $\mathrm{kg} / \mathrm{d}$ & $1.42^{\mathrm{b}}$ & 0.033 & $1.55^{\mathrm{a}}$ & 0.019 \\
\hline Protein & $\mathrm{g} / \mathrm{d}$ & $529.5^{\mathrm{b}}$ & 17.243 & $569.3^{\mathrm{a}}$ & 7.700 \\
\hline Casein & $\mathrm{g} / \mathrm{d}$ & $408.4^{\mathrm{b}}$ & 15.472 & $476.6^{\mathrm{a}}$ & 9.720 \\
\hline Fat & $\mathrm{g} / \mathrm{d}$ & 578.7 & 33.538 & 594.8 & 38.425 \\
\hline Lactose & $\mathrm{g} / \mathrm{d}$ & $794.4^{b}$ & 17.106 & $857.4^{\mathrm{a}}$ & 16.101 \\
\hline
\end{tabular}

a,b means in the same row with different superscripts differ significantly $(\mathrm{P}<0.05)$

${ }^{1,2}$ see Table 2

The contents of fat and lactose were within normal physiological ranges and were not affected by treatment $(\mathrm{P}>0.05)$. The concentration of urea in $\mathrm{C}$ milk was significantly higher than in $\mathrm{T}$ milk $(\mathrm{P}<0.05)$. 
Because of the differences in DM intake, daily yield and composition of milk was converted according to dry matter intake (Table 5). Recalculated mean milk Table 5. Daily yield of milk and milk constituents converted according to dry matter (DM) intake

\begin{tabular}{lcccccc}
\hline \multirow{2}{*}{ Item } & \multirow{2}{*}{ Unit } & \multicolumn{3}{c}{$\mathrm{C}^{1}(\mathrm{n}=24)$} & & \multicolumn{2}{c}{$\mathrm{T}^{2}(\mathrm{n}=24)$} \\
\cline { 3 - 4 } \cline { 3 - 4 } & & $\mathrm{mean}$ & $\mathrm{SEM}$ & & mean & $\mathrm{SEM}$ \\
\hline Milk yield/DM intake & $\mathrm{kg} / \mathrm{kg}$ & 1.08 & 0.034 & & 1.09 & 0.021 \\
FCM/DM intake & $\mathrm{kg} / \mathrm{kg}$ & 0.98 & 0.036 & & 0.98 & 0.032 \\
FCM/NEL & $\mathrm{kg} / \mathrm{MJ}$ & 0.16 & 0.006 & & 0.16 & 0.005 \\
Protein/DM intake & $\mathrm{g} / \mathrm{kg}$ & 33.84 & 0.958 & & 35.08 & 0.749 \\
Casein/DM intake & $\mathrm{g} / \mathrm{kg}$ & $26.02^{\mathrm{b}}$ & 0.760 & & $29.33^{\mathrm{a}}$ & 0.697 \\
Fat/DM intake & $\mathrm{g} / \mathrm{kg}$ & 36.75 & 1.877 & & 36.02 & 2.041 \\
Lactose/DM intake & $\mathrm{g} / \mathrm{kg}$ & 51.18 & 1.585 & & 52.79 & 1.229 \\
\hline
\end{tabular}

a,b means in the same row with different superscripts differ significantly $(\mathrm{P}<0.05)$

${ }_{1,2}$ see Table 2

yield, 4\% FCM, milk fat yield reached almost the same values, whereas milk protein yield was not affected $(\mathrm{P}>0.05)$ but tended to be higher when tablets $(\mathrm{T})$ were given. Recalculated casein yield was significantly higher $(\mathrm{P}<0.05)$ when soya protein and amino acids were supplemented in the form of tablets $(\mathrm{T})$.

The mean values of somatic cell counts (SCC) were similar in both groups. None of the characteristics of milk processability observed differed significantly $(\mathrm{P}>0.05)$ between treatments (Table 6).

Table 6. Technological suitability of milk

\begin{tabular}{|c|c|c|c|c|c|}
\hline \multirow{3}{*}{ Parameter } & \multirow{3}{*}{ Unit } & \multicolumn{4}{|c|}{ Group } \\
\hline & & \multicolumn{2}{|c|}{$\mathrm{C}^{1}(\mathrm{n}=24)$} & \multicolumn{2}{|c|}{$\mathrm{T}^{2}(\mathrm{n}=24)$} \\
\hline & & mean & SEM & mean & SEM \\
\hline $\begin{array}{l}\text { Fermentation } \\
\text { activity }\end{array}$ & ${ }^{\circ} \mathrm{SH}$ & 24.30 & 1.623 & 23.49 & 1.249 \\
\hline Titratable acidity & ${ }^{\circ} \mathrm{SH}$ & 7.53 & 0.376 & 7.11 & 0.321 \\
\hline $\mathrm{pH}$ & & 6.46 & 0.053 & 6.50 & 0.056 \\
\hline Freezing point & ${ }^{\circ} \mathrm{C}$ & -0.530 & 0.004 & -0.527 & 0.003 \\
\hline Milk conductivity & $\mathrm{mS} / \mathrm{cm}$ & 5.96 & 0.152 & 5.72 & 0.078 \\
\hline Somatic cell count & $10^{3} / \mathrm{mL}$ & 192 & 33.911 & 200 & 27.982 \\
\hline
\end{tabular}

${ }_{1,2}$ see Table 2

Milk fatty acid profiles are presented in Table 7 . The proportions of shortchain fatty acids $(\mathrm{C} 4: 0-\mathrm{C} 12: 0)$ were decreased $(\mathrm{P}<0.05)$ when soya-protein and $\mathrm{AA}$ in the form of rumen-protected tablets $(\mathrm{T})$ were supplemented. Addition of tablets $(\mathrm{T})$ reduced the proportion of $\mathrm{C} 14: 0$ and $\mathrm{C} 16: 0$ medium-chain fatty acids $(\mathrm{P}<0.05)$. Monounsaturated medium-chain FA were not significantly 
Table 7. Fatty acid profiles, $\%$

\begin{tabular}{|c|c|c|c|c|}
\hline \multirow{3}{*}{ Fatty acid } & \multicolumn{4}{|c|}{ Group } \\
\hline & \multicolumn{2}{|c|}{$\mathrm{C}^{1}(\mathrm{n}=24)$} & \multicolumn{2}{|c|}{$\mathrm{T}^{2}(\mathrm{n}=24)$} \\
\hline & Mean & SEM & mean & SEM \\
\hline C4:0 & $1.67^{\mathrm{b}}$ & 0.071 & $1.56^{\mathrm{a}}$ & 0.101 \\
\hline C6:0 & $1.45^{\mathrm{b}}$ & 0.073 & $1.34^{\mathrm{a}}$ & 0.106 \\
\hline C8:0 & $0.98^{\mathrm{b}}$ & 0.056 & $0.90^{\mathrm{a}}$ & 0.076 \\
\hline C10:0 & $2.20^{\mathrm{b}}$ & 0.136 & $2.02^{\mathrm{a}}$ & 0.171 \\
\hline C12:0 & $2.83^{b}$ & 0.165 & $2.60^{\mathrm{a}}$ & 0.169 \\
\hline C14:0 & $10.63^{b}$ & 0.378 & $10.01^{\mathrm{a}}$ & 0.310 \\
\hline C14:1 & 1.31 & 0.066 & 1.27 & 0.062 \\
\hline C16:0 & $35.72^{b}$ & 1.477 & $31.99^{\mathrm{a}}$ & 0.559 \\
\hline C16:1 & 2.54 & 0.066 & 2.64 & 0.154 \\
\hline C18:0 & 7.95 & 0.442 & 8.47 & 0.320 \\
\hline C18:1 & $28.75^{\mathrm{b}}$ & 1.711 & $32.74^{\mathrm{a}}$ & 1.418 \\
\hline $\mathrm{C} 18: 2 \mathrm{n}$ & $2.99^{b}$ & 0.108 & $3.32^{\mathrm{a}}$ & 0.089 \\
\hline C18:3n6 & 0.11 & 0.006 & 0.10 & 0.002 \\
\hline $\mathrm{C} 18: 3 \mathrm{n} 3$ & $0.26^{\mathrm{b}}$ & 0.010 & $0.30^{\mathrm{a}}$ & 0.012 \\
\hline C20:1 & $0.31^{\mathrm{b}}$ & 0.019 & $0.44^{\mathrm{a}}$ & 0.032 \\
\hline $\mathrm{C} 20: 4 \mathrm{n} 6$ & $0.18^{\mathrm{b}}$ & 0.006 & $0.16^{\mathrm{a}}$ & 0.007 \\
\hline $\mathrm{C} 20: 5 \mathrm{n} 3$ & 0.03 & 0.002 & 0.03 & 0.003 \\
\hline $\mathrm{C} 22: 4 \mathrm{n} 6$ & 0.03 & 0.001 & 0.03 & 0.001 \\
\hline $\mathrm{C} 22: 5 \mathrm{n} 6$ & 0.02 & 0.001 & 0.02 & 0.001 \\
\hline $\mathrm{C} 22: 5 \mathrm{n} 3$ & 0.03 & 0.003 & 0.04 & 0.003 \\
\hline $\mathrm{C} 22: 6 \mathrm{n} 3$ & 0.02 & 0.001 & 0.02 & 0.001 \\
\hline $\mathrm{SFA}^{3}$ & $63.43^{\mathrm{b}}$ & 1.789 & $58.88^{\mathrm{a}}$ & 1.642 \\
\hline $\mathrm{UFA}^{4}$ & $36.57^{\mathrm{b}}$ & 1.789 & $41.12^{\mathrm{a}}$ & 1.642 \\
\hline MUFA $^{5}$ & $32.91^{\mathrm{b}}$ & 1.692 & $37.08^{\mathrm{a}}$ & 1.585 \\
\hline PUFA $^{6}$ & $3.67^{\mathrm{b}}$ & 0.123 & $4.03^{\mathrm{a}}$ & 0.092 \\
\hline SFA/MUFA & $2.12^{\mathrm{b}}$ & 0.174 & $1.70^{\mathrm{a}}$ & 0.115 \\
\hline SFA/PUFA & $18.00^{\mathrm{b}}$ & 0.954 & $14.94^{\mathrm{a}}$ & 0.687 \\
\hline SFA/UFA & $1.89^{\mathrm{b}}$ & 0.148 & $1.52^{\mathrm{a}}$ & 0.099 \\
\hline MUFA/PUFA & 8.94 & 0.317 & 9.19 & 0.307 \\
\hline
\end{tabular}

${ }^{\mathrm{a}, \mathrm{b}}$ means in the same row with different superscripts differ significantly $(\mathrm{P}<0.05)$

${ }^{1,2}$ see Table 2

3 saturated fatty acids

${ }^{4}$ unsaturated fatty acids

${ }^{5}$ monounsaturated fatty acids

${ }^{6}$ polyunsaturated fatty acids

affected $(\mathrm{P}>0.05)$ by the treatment. The content of $\mathrm{C} 18: 1, \mathrm{C} 18: 2, \mathrm{C} 18: 3 \mathrm{n} 3$ and $\mathrm{C} 20: 1$ was lower in $\mathrm{C}$ milk $(\mathrm{P}<0.05)$ compared with $\mathrm{T}$ milk. Administration of soya-protein and AA in the form of rumen-protected tablets $(\mathrm{T})$ increased the proportion of unsaturated FA (both MUFA and PUFA) and decreased saturated FA in milk $(\mathrm{P}<0.05)$. The total saturated:unsaturated fatty acid ratio was higher 
Table 8 . Yield of individual fatty acids, g/d

\begin{tabular}{|c|c|c|c|c|}
\hline \multirow{3}{*}{ Fatty acid } & \multicolumn{4}{|c|}{ Group } \\
\hline & \multicolumn{2}{|c|}{$C^{1}(n=24)$} & \multicolumn{2}{|c|}{$\mathrm{T}^{2}(\mathrm{n}=24)$} \\
\hline & mean & SEM & mean & SEM \\
\hline $\mathrm{C} 4: 0$ & 10.01 & 0.892 & 9.96 & 1.110 \\
\hline C6:0 & 8.71 & 0.746 & 8.74 & 1.067 \\
\hline C8:0 & 5.88 & 0.507 & 5.91 & 0.756 \\
\hline C10:0 & 13.16 & 1.178 & 13.18 & 1.658 \\
\hline C12:0 & 16.73 & 1.366 & 16.59 & 1.840 \\
\hline C14:0 & 62.50 & 4.466 & 61.54 & 5.329 \\
\hline C14:1 & 7.52 & 0.485 & 7.32 & 0.426 \\
\hline C16:0 & 207.66 & 14.094 & 193.67 & 14.492 \\
\hline C16:1 & 14.40 & 0.676 & 14.89 & 0.825 \\
\hline C18:0 & 47.14 & 4.315 & 52.65 & 5.004 \\
\hline C18:1 & $162.5^{\mathrm{b}}$ & 10.875 & $184.50^{\mathrm{a}}$ & 7.902 \\
\hline C18:2n & $16.85^{\mathrm{b}}$ & 0.859 & $19.21^{\mathrm{a}}$ & 0.999 \\
\hline C18:3n6 & 0.61 & 0.039 & 0.63 & 0.044 \\
\hline C18:3n3 & $1.47^{\mathrm{b}}$ & 0.078 & $1.76^{\mathrm{a}}$ & 0.108 \\
\hline C20:1 & $1.76^{\mathrm{b}}$ & 0.135 & $2.47^{\mathrm{a}}$ & 0.164 \\
\hline $\mathrm{C} 20: 4 \mathrm{n} 6$ & 1.05 & 0.068 & 1.02 & 0.094 \\
\hline $\mathrm{C} 20: 5 \mathrm{n} 3$ & 0.18 & 0.019 & 0.21 & 0.033 \\
\hline $\mathrm{C} 22: 4 \mathrm{n} 6$ & 0.19 & 0.014 & 0.20 & 0.017 \\
\hline $\mathrm{C} 22: 5 \mathrm{n} 6$ & 0.11 & 0.009 & 0.11 & 0.010 \\
\hline $\mathrm{C} 22: 5 \mathrm{n} 3$ & $0.19^{b}$ & 0.020 & $0.23^{\mathrm{a}}$ & 0.024 \\
\hline C22:6n3 & 0.10 & 0.010 & 0.10 & 0.008 \\
\hline $\mathrm{SFA}^{3}$ & 371.79 & 25.249 & 362.22 & 30.712 \\
\hline $\mathrm{UFA}^{4}$ & $206.89^{b}$ & 12.532 & $232.61^{\mathrm{a}}$ & 9.901 \\
\hline MUFA $^{5}$ & 186.18 & 11.603 & 209.17 & 8.922 \\
\hline PUFA $^{6}$ & $20.71^{b}$ & 1.062 & $23.45^{\mathrm{a}}$ & 1.282 \\
\hline SFA/MUFA & $12.52^{\mathrm{b}}$ & 1.198 & $10.93^{\mathrm{a}}$ & 1.256 \\
\hline SFA/PUFA & $107.07^{b}$ & 8.774 & $93.78^{\mathrm{a}}$ & 9.309 \\
\hline SFA/UFA & $11.18^{\mathrm{b}}$ & 1.045 & $9.76^{\mathrm{a}}$ & 1.099 \\
\hline MUFA/PUFA & 53.66 & 3.599 & 53.15 & 3.111 \\
\hline
\end{tabular}

${ }^{a, b}$ means in the same row with different superscripts differ significantly $(\mathrm{P}<0.05)$

${ }^{1,2}$ see Table 2

${ }^{3}$ saturated fatty acids

${ }^{4}$ unsaturated fatty acids

${ }^{5}$ monounsaturated fatty acids

${ }^{6}$ polyunsaturated fatty acids

on the $\mathrm{C}$ treatment compared with $\mathrm{T}(\mathrm{P}<0.05)$. The yields of individual fatty acids are presented in Table 8 . The yield of short- and medium-chain fatty acids was not affected by the treatment $(\mathrm{P}>0.05)$. The daily yield of the following unsaturated fatty acids: C18:1, C18:2n, C18:3n3, C20:1, C22:5n3 was significantly lower 
$(\mathrm{P}<0.05)$ in $\mathrm{C}$ milk than in T milk. The higher yield of unsaturated fatty acids in $\mathrm{T}$ mentioned above resulted in lower SFA:UFA, SFA:MUFA and SFA:PUFA ratios $(\mathrm{P}<0.05)$.

\section{DISCUSSION}

The major part of the amino acid requirement of lactating dairy cows is met by postruminal digestion of microbial protein, nevertheless, diets for highyielding cows may not meet the requirements for all amino acids. Volden et al. (1998) found that the mean rumen escape values of threonine, methionine and lysine given intraruminally in non-protected form were 16.7, 22.1 and $20.5 \%$, respectively. The response to feeding protected amino acids reported in the literature is variable depending on the source of protein in the basal diet. The postruminal supply of specific amino acids can be increased by supplementing the diet with polymerically encapsulated amino acids (Papas et al., 1984). Methionine alone in this form has failed to improve milk yield or growth in ruminants (Papas et al., 1984) while another form of rumen-protected methionine added to diets containing soyabean meal as the supplemental protein source has increased milk production. In the presented experiment, a mixture of soyaprotein and the amino acids Met, Lys and His was encapsulated by copolymer and proved more effective than the same mixture without encapsulation, as discussed in details later.

In the experiment we found that the dry matter intake of cows receiving tablets ( $T$ ) was significantly higher $(\mathrm{P}<0.05)$, thus the intake of other nutrients was also higher. Similar responses or non-significant trends were presented in other studies (e.g., Schwab et al., 1992; Vanhatalo et al., 1999). On the other hand, in some studies no effect of rumen-protected Met or duodenally infused Lys on feed intake was observed (e.g., Rulquin and Delaby, 1997).

Published results from studies when Lys, Met and His have been supplemented in rumen-protected form or infused postruminally are scarce and there is no study on the effect of supplementing soya-protein + these three amino acids. We found that the average milk yield recorded in $\mathrm{C}$ was significantly lower than that in $\mathrm{T}$. Similarly, Vanhatalo et al. (1999) observed that the milk yield of cows increased $(\mathrm{P}=0.01)$ after infusions of $6.5 \mathrm{~g}$ His $+6 \mathrm{~g}$ Met $+19 \mathrm{~g}$ Lys compared with the control group without AA infusions, whereas energy corrected milk (ECM) yield was not affected. In our experiment, milk yield recalculated to 4\% FCM was not influenced by the form of AA supplementation ( $P>0.05)$. Fraser et al. (1991) suggested His in microbial protein to be the only limiting AA for milk production and reported also significant reduction in milk and milk protein yields due to 
removal of Lys and His, but not Met, from an abomasal infusion of EAA mixture in cows that were maintained by total intragastric infusion of nutrients.

Although the milk protein percentage did not differ significantly $(\mathrm{P}>0.05)$, the milk protein yield from $\mathrm{C}$ cows was lower than that from $\mathrm{T}$ cows $(\mathrm{P}<0.05)$. Furthermore, the casein content and yield recorded in $\mathrm{T}$ was higher $(\mathrm{P}<0.05)$ as was the proportion of casein proteins in total milk protein. Our findings are in agreement with Vanhatalo et al. (1999) who did not find any effects of Met, Lys and His infusions on the protein content of milk, however, they noted that the milk protein content was higher $(\mathrm{P}=0.02)$ when His was combined with Met rather than Lys. Infusions of the three amino acids did, however, increase the milk protein yield $(\mathrm{P}=0.007)$ and consequently raised the protein-to-fat ratio of milk $(\mathrm{P}=0.007)$. Cant et al. (1997) have shown that removal of His from abomasally infused mixtures of AA caused reduced yields of milk protein. Choung and Chamberlain (1995) reported an increase of $26 \%$ in the protein yield of cows fed a grass silage diet in response to intravenous infusion of an AA mixture including His, Lys, Met and Trp. Removal of Met from the mixture did not affect protein yield. From comparison of AA concentrations in microbial and whole digesta and feeds used in the experiment, they concluded that His is the first-limiting AA in the mixture of the remaining three amino acids infused abomasally in their experiment. Similarly, by comparing bacterial AA composition in relation to milk protein, Oldham (1987) suggested that His could be the first limiting AA in ruminants. The significant increases in yields of milk and milk protein caused by administration of rumen-protected tablets containing soya-protein, Lys, Met and His into the rumen of cows confirms the general claim that Met and Lys are the first-limiting AA for production and His is a potentially third limiting AA in maize-based diets. The differences in responses to AA suggest that the basal diet and the nutritional status of the cow have important effects on responses. Published values of the arterial His concentration on maize silage (e.g., Schwab et al., 1992; Pisulewski et al., 1996), have varied in the range of 35 to $76 \mu \mathrm{mol} / \mathrm{L}$ and thus have been much higher than the respective concentrations on grass silage diets (Vanhatalo et al., 1999). That is why recent AA infusion studies (Vanhatalo et al., 1999; Huhtanen et al., 2002) suggest that His is the first-limiting AA on grass silage, cereal-based diets.

The contents of fat and lactose observed in our study were within normal physiological ranges and were not affected by treatment $(\mathrm{P}>0.05)$. This is in contrast to the study performed by Vanhatalo et al. (1999) who found that the lactose and fat contents decreased $(\mathrm{P} \leq 0.03)$ when Met, Lys and His were infused together, but that the fat content tended to be higher $(\mathrm{P}=0.08)$ when His was combined with Met rather than Lys. On the other hand, neither the infusions of the three amino acids (Vanhatalo et al., 1999) nor the tablets (T) affected lactose and fat yields. We found 
that the concentration of urea in $\mathrm{C}$ was significantly higher than that found in $\mathrm{T}$, which is in disagreement with Vanhatalo et al. (1999) who observed that infusions of His in combination with Met and Lys had no influence on milk urea content. They mentioned, however, that milk urea tended to be lower when all three AA were infused together as compared with the combinations of two AA. Similar results were presented by Pisulewski et al. (1996) who found that the urea concentration in milk was not affected by graded amounts of Met infusion.

Because of the differences in DM intake, daily yield and composition of milk were recalculated according to dry matter intake. Recalculated mean milk yield, $4 \%$ FCM, milk fat and milk protein yield were not influenced by treatment $(\mathrm{P}>0.05)$. Similarly Schwab et al. (1992) found that treatment did not affect the efficiency of production of 4\% FCM from dry matter intake. We observed, however, a higher recalculated casein yield $(\mathrm{P}<0.05)$ after supplementation of soya-protein with amino acids in the form of tablets $(\mathrm{T})$.

None of the observed characteristics important for technological suitability of milk differed significantly between treatments $(\mathrm{P}>0.05)$. The results obtained from this experiment are different from those presented by Grega et al. (1999), who found that rumen-protected Met or Met+Lys favoured the qualities required for cheese milk.

After the administration of tablets $(\mathrm{T})$, the proportion of short- and mediumchain FA decreased $(\mathrm{P}<0.05)$. Our findings are in discrepancy with Christensen et al. (1994) who found that supplementation of rumen-protected AA to the diet tended to increase the proportion of $\mathrm{C} 10: 0$ and slightly increased the proportions of $\mathrm{C} 12: 0$ and $\mathrm{C} 14: 0$ in milk fat. The proportion of $\mathrm{C} 16: 1$ was lower, and the proportion of $\mathrm{C} 18: 1$ was slightly lower in milk fat from cows supplemented with rumen-protected AA. Similarly, Pisulewski et al. (1996) found that the infusion of Met into the duodenum of early lactating cows increased the proportions of short- and medium-chain fatty acids and decreased the proportion of long-chain fatty acids in milk fat. That is why he suggested that Met may have an impact on de novo synthesis of short- and medium-chain fatty acids in the mammary gland.

The ratios of the main groups of fatty acids are considered to be very important markers of healthy human nutrition. In this experiment, the SFA content in C milk was significantly higher and the UFA content was lower $(\mathrm{P}<0.05)$ than in $\mathrm{T}$ milk. Reducing the SFA content and increasing that of long-chain UFA have been associated with increased healthfulness of milk. In terms of human health, these changes may represent an improvement in the FA profile of milk because mediumchain FA and SFA have been reported to constitute the hypercholesterolemic portion of milk fat. Although the SFA content in C milk was higher (63.43) than in $\mathrm{T}(58.88 ; \mathrm{P}<0.05)$, the $\mathrm{T}$ milk contained more of stearic acid. Kennely and Glimm (1998) suggest, however, that stearic acid, despite its saturated nature, 
is as effective as C18:1 in reducing plasma cholesterol in humans. Despite milk being considered a relatively poor source of essential PUFAs (Kennely and Glimm, 1998), after administration of tablets (T) the experimental group had a significantly higher $(\mathrm{P}<0.05)$ content of PUFA than the control group.

\section{CONCLUSIONS}

Mean milk yield expressed in 4\% FCM, protein, fat and lactose content was unaffected by the supplementation of the rumen-protected protein and amino acids in the form of tablets, nevertheless the protein content tended to increase and the fat content tended to decrease when tablets were given. Protein yield was higher and was followed closely by progressive increases in casein content and yield, a higher proportion of casein protein in total milk protein was observed as well when the tablets were given to cows. The proportions of short- and medium-chain fatty acids were decreased and the content of C18:1, C18:2, C18:3n3 and C20:1 in milk was increased with AA supplementation. The proportion of UFA (both MUFA and PUFA) increased and SFA decreased when tablets were given. Thus, the results reported in the current study suggest that supplementation with rumenprotected tablets containing soya-protein and limiting amino acids (Lys, Met, His) is an effective way to influence milk yield and composition.

\section{REFERENCES}

AOAC, 1984. Official Methods of Analysis, Association of Official Analytical Chemists. 14 Edition. Washington, DC

Ardaillon P., Antant P., Bourrain P., Cartillier A., 1989. Compositions for coating feedstuff additives thus coated. United States Patent, US 4, 877,621

Cant J. P., Trout D. R., Qiao F., McBride B. W., 1997. Milk composition responses to unilateral infusion of amino acid mixtures. J. Dairy Sci. 80, Suppl. 1, 53 (Abstr.)

Choung J.J., Chamberlain D.G., 1995. The effects of intravenous supplements of amino acids on milk production of dairy cows consuming grass silage and supplement containing feather meal. J. Sci. Food Agr. 68, 265-270

Christensen R.A., Cameron M.R., Clark J.H., Drackley J.K., Lynch J.M., Barbano D.M., 1994. Effects of amount of protein and ruminally protected amino acids in the diet of dairy cows fed supplemental fat. J. Dairy Sci. 77, 1618-1629

Fraser D.L., Ørskov E.R., Withelaw F.G., Franklin M.F., 1991. Limiting amino acids in dairy cows given casein as the sole source of protein. Livest. Prod. Sci. 28, 235-252

Grega T., Pisulewski P., Kowalski Z. M., Sady M., 1999. Effect of rumen-protected amino acids (Llysine and DL-methionine) on processing quality of milk. Pol. J. Food Nutr. Sci. 8/49, 91-100

Huhtanen P., Vanhatalo A., Varvikko T., 2002. Effects of abomasal infusions of histidine, glucose, and leucine on milk production and plasma metabolites of dairy cows fed grass silage diets. J. Dairy Sci. 85, 204-216 
Kennely J.J., Glimm D.R., 1998. The biological potential to alter the composition of milk. Can. J. Anim. Sci. 78, Suppl., 23-56

Korhonen M., Vanhatalo A., Varvikko T., Huhtanen P., 2000. Responses to graded postruminal doses of histidine in dairy cows fed grass silage diets. J. Dairy Sci. 83, 2596-2608

Krober T.F., Sutter F., Senn M., Langhans W., Kreuzer M., 2001. Effects of supplying leucine and methionine to early-lactating cows fed silage-concentrate based diets with a calculated deficiency in leucine and methionine. Anim. Res. 50, 5-20

Oldham J.D., 1987. Efficiencies of amino acid utilization. In: R. Jarrige, G. Alderman (Editors). Feed Evaluation and Protein Requirement Systems for Ruminants. European Economic Union, Brussels, pp. 171-186

Papas A.M., Vicini J.L., Clark J.H., Pierce-Sandner S., 1984. Effect of rumen-protected methionine on plasma free amino acids and production by dairy cows. J. Nutr. 114, 2221-2238

Pisulewski P.M., Rulquin H., Peyraud J.L., Verite R., 1996. Lactational and systemic responses of dairy cows to postruminal infusions of increasing amounts of methionine. J. Dairy Sci. 79, $1781-1791$

Rulquin H., 2001. Acides aminés digestibles dans 1'intestin. INRA Prod. Anim. 14, 275-278

Rulquin H., Delaby L., 1997. Effects of the energy balance of dairy cows on lactational responses to rumen-protected methionine. J. Dairy Sci. 80, 2513-2522

Schwab C.G., Bozak C.K., Whitehouse N.L., Olson V.M., 1992. Amino acid limitation and flow to the duodenum at four stages of lactation. 2. Extent of lysine limitation. J. Dairy Sci. 75, 35033518

Sommer A., Frydrych Z., Vencl B., 1994. Nutrient Requirement and Tables of Nutritional Values of Feedstuffs for Ruminants. Editor: Research Institute of Animal Nutrition, Pohořelice, pp. 198

Vanhatalo A, Huhtanen P., Toivonen V., Varvikko T., 1999. Response of dairy cows fed grass silage diets to abomasal infusions of histidine alone or in combinations with methionine and lysine. J. Dairy Sci. 82, 2674-2685

Volden H., Velle W., Harstad O.M., Aulie A., Sjaastad O.V., 1998. Ruminal degradation and rumen escape of lysine methionine and threonine administered intraruminally in mixtures to highyielding cows. J. Anim. Sci. 76, 1232-1240

Xu S., Harrison J.H., Chalupa W., Sniffen C., Julien W., Sato H., Fujieda T., Watanabe K., Ueda T., Suzuki H., 1998. The effect of ruminal bypass lysine and methionine on milk yield and composition of lactating cows. J. Dairy Sci. 81, 1062-1077 